\title{
From social accessory to societal disapproval: smoking, social norms and tobacco endgames
}

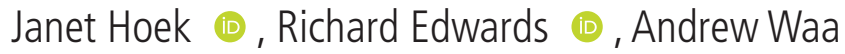

Department of Public Health, University of Otago, Wellington, New Zealand

\section{Correspondence to}

Professor Janet Hoek, Public Health, University of Otago, Wellington 6242, New Zealand; janet.hoek@otago.ac.nz
Check for updates

(C) Author(s) (or their employer(s)) 2022. No commercial re-use. See rights and permissions. Published by BMJ.

To cite: Hoek J, Edwards R, Waa A. Tob Control

2022:31:358-364.

\section{INTRODUCTION}

Described as 'unwritten rules', 1 social norms affect how we interact with others, define which practices we regard as acceptable and serve as heuristics that simplify our decision-making. Norms evolve as shared practices, then become embedded within social groups; once established, they shape and reinforce perceptions of commonly practised behaviours (ie, descriptive norms) that attract social approval or disapproval (ie, injunctive norms). ${ }^{2}$ Because normative practices may define social group membership and serve as markers of identity and belonging, they become self-enforcing and help to attract new members. ${ }^{3-5}$

Environments play a critical role in enabling and supporting practices, and thus in creating and embedding social norms. For example, dispensing cigarettes to soldiers and providing ashtrays in public areas signalled smoking's acceptability, reinforced its normativity within specific settings and helped entrench it as a social practice. ${ }^{6-8}$ However, environments may also discourage and extinguish social practices. More recently, smoke-free signage has declared that smoking is not acceptable within designated settings, ${ }^{9} 10$ while removal of large in-store tobacco displays sharply differentiated tobacco from normal consumer goods. ${ }^{11} 12$

Lopez et al's four-phase model of the smoking epidemic describes how social norms changed as smoking practices diffused and after knowledge of smoking's harms increased. ${ }^{13}$ During the innovation and establishment phase, smoking's social acceptance increased, followed by rapidly increasing prevalence as new population groups adopted smoking. ${ }^{713}$ Smoking prevalence peaked near the end of the second phase, then declined as knowledge of its harms emerged, prompting regulation, stimulating cessation and reducing its social acceptability. ${ }^{13}$ Prevalence declined further in the final phase as evidence of smoking's health risks grew and denormalisation, or loss of social acceptability, increased. ${ }^{13}$ Western countries, many of which have strong smoke-free policies, provide the clearest illustration of these phases, which are more apparent in high-income countries than in low/middle-income countries. ${ }^{14}$

In this commentary, we draw on Lopez et al's model to outline how smoking-using commercially produced and supplied tobacco-evolved as a socially normative practice. We then discuss its subsequent relocation outside accepted social boundaries, review smoking denormalisation and its implications, and propose a fifth phase: the endgame phase. We conclude by considering tobacco companies' rapidly evolving product array and quest for renormalisation, and explore how the industry's renewed efforts to influence social norms could affect tobacco endgame strategies and people who smoke.

\section{PHASE 1: ESTABLISHMENT OF CIGARETTE SMOKING AS A NORMATIVE SOCIAL PRACTICE}

Like any new practice, cigarette smoking was initially confined to early adopters; cigarettes were relatively expensive because mass production technologies had not evolved and affordability constrained diffusion. Furthermore, social practices featuring smoking needed to evolve and existing practices had to realign to accommodate smoking. Early adoption thus occurred primarily among men from higher income groups who had the resources and social capital to model new practices that others observed and subsequently adopted. ${ }^{13}$ 15-17 Through respondent conditioning, smoking came to represent aspirational attributes that differentiated social class, prompted imitation and uptake across traditional social boundaries, and became increasingly normative. ${ }^{717-19}$

\section{PHASE 2: RAPIDLY INCREASING SMOKING PREVALENCE}

During the second phase, three key factors accelerated smoking's establishment as a socially normative practice. ${ }^{20-22}$ First, technological innovations allowed industrial-scale production of cigarettes, which simultaneously reduced costs, increased availability, ${ }^{7}$ and positioned tobacco companies as normal businesses meeting consumer demand and supporting local economies. ${ }^{13}$ Second, tobacco companies undertook extensive marketing campaigns to target specific population groups. $^{20}$ 23-27 Third, social environments accommodated and validated smoking as an accepted practice. $^{8} 28$

Among targeted population groups, women received particular attention and tobacco companies positioned smoking as a symbol of emancipation that could disrupt entrenched gender discrimination precluding women from roles outside domestic environments. ${ }^{23} 29$ Segregation of African American communities enabled tobacco companies to launch an 'advertising assault' 20 on community members and aggressively target menthol brands. Marketing to Lesbian, Gay, Bisexual and Transgender (LGBT) communities framed tobacco companies as civil liberty champions who acknowledged and validated marginalised groups by creating unique brand offerings. $^{24} 27$ Positioned as symbols of community 
membership, these brands replaced ostracism with connection and provided a conduit to status and social acceptance. ${ }^{202430}$

As well as creating differentiated brands, tobacco companies integrated smoking-related paraphernalia into social settings. Ashtrays, complimentary cigarettes, and lighters welcomed and normalised smoking, and staked out spaces as 'smoking-friendly'. ${ }^{8}$ New words legitimising smoking emerged ${ }^{28}{ }^{31}$; in Australasia 'smoko' evolved from a slang term describing morning and afternoon breaks into a word used in workers' rights legislation. ${ }^{31}$ Product placement saw tobacco brands and smoking strategically located in movies, and associated with youth role models, ${ }^{32} 33 \mathrm{a}$ strategy that increased smoking initiation among young people and helped recruit 'replacement smokers'. ${ }^{34-36}$

During this phase, widespread product availability, reduced product costs and sophisticated marketing embedded smoking as a social practice. Brands served as badges of identity, ${ }^{37}$ language evolved to reinforce smoking's normativity and prevalence grew rapidly as smoking was carried within social networks. ${ }^{4}$ What could possibly go wrong?

\section{PHASE 3: SMOKING PREVALENCE DECLINES AND THE TOBACCO INDUSTRY RESPONDS}

The third phase represents declines in smoking prevalence and social acceptability following smoking's heyday. These changes responded to research linking smoking with lung cancer, a previously rare disease, ${ }^{38}$ and were accompanied by growing public anxiety, a plateau and then decline in smoking prevalence, and increasing concerns about the tobacco industry's behaviour and legitimacy. ${ }^{39} 40$

Tobacco companies responded to this threat by launching a masterful public relations campaign, the 'Frank Statement', which reached more than 40 million Americans. The Frank Statement questioned whether smoking caused lung cancer, reassured people tobacco products were safe and declared tobacco companies saw their 'interest in public health as a basic responsibility, paramount to every other consideration in [their] business'. ${ }^{41}$ Yet, despite the pledges outlined, tobacco companies challenged scientific evidence outlining the risks of smoking, questioned health authorities, attacked individual scientists and made a concerted effort to create doubt about research documenting smoking's serious health effects. ${ }^{42-47}$

At the same time as undermining public health science, tobacco companies promoted scientific 'innovations', including cigarette filters, as risk reduction technologies. ${ }^{48}$ While research has now shown that filters do not reduce the toxicity of inhaled smoke, ${ }^{49}$ people who smoked saw filters as harm reduction tools and an alternative to quitting, and quickly began using them. ${ }^{49-51}$ Tobacco companies capitalised on harm reduction connotations by introducing filter ventilation and deceptively named 'light' and 'mild' brand variants that reinforced reduced harm misperceptions and maintained smoking's social acceptability. ${ }^{52-54}$

\section{PHASE 4: DENORMALISATION}

The final phase of Lopez et al's model describes continuing declines in smoking prevalence, expanding knowledge of smoking's harms and increased smoke-free regulation. As knowledge that industry 'innovations' would not deliver public health gains grew, regulators began dismantling the marketing edifice that maintained smoking's normativity. Policies restricted tobacco promotions and education campaigns increased the public's knowledge of smoking's risks. For example, on-pack warnings began featuring graphic depictions of harms caused by smoking, ${ }^{55}$ while fear appeals, the antithesis of consumer marketing, signalled that smoking was not a benign indulgence but a life-threatening activity. ${ }^{57-60}$

Many countries introduced measures to protect young people from smoking uptake, including minimum purchase age laws ${ }^{61}$ and excise tax increases. ${ }^{62}$ Youth-oriented social marketing, such as the American Legacy Foundation's Truth ${ }^{\circledR}$ campaign also began. ${ }^{41}{ }^{63-67}$ The Truth ${ }^{\circledR}$ campaign exposed tobacco companies as manipulative and dishonest, challenged smoking as a symbol of independence ${ }^{68}$ and successfully positioned smoke-free behaviour as normative. ${ }^{69} 70$ Known collectively as denormalisation, these measures fundamentally changed smoking's social status. ${ }^{71} 72$

Estimates that exposure to secondhand smoke caused hundreds of thousands of premature deaths every year (currently estimated at 1.2 million) increased the urgency of policy measures mandating smoke-free spaces and saw non-smokers' advocacy groups develop. ${ }^{93-76}$ Despite tobacco companies' counteroffensives to challenge research findings, ${ }^{77-80}$ assert smokers' rights ${ }^{81} 82$ and promote a 'considerate smoker' persona, ${ }^{83}$ regulators in many countries established and expanded smoke-free areas. $^{75}$

Yet, while they may not have prevented stronger regulation, tobacco companies nonetheless influenced debate by reframing smoking not as an addiction, but as a 'habit', a term that persists today. ${ }^{885}$ This term locates agency within people who smoke and enabled the tobacco industry to present smoking as an 'informed choice', made in full knowledge of the risks involved. ${ }^{86}$ 'Personal choice' arguments later created an important defence in product liability suits and reduced public sympathy for plaintiffs by depicting them as victims of their own actions. ${ }^{87-89}$

By the late 20th century, many countries had begun introducing policies to reduce the impact smoking had on population health; internationally, these concerns culminated in the Framework Convention on Tobacco Control (FCTC).$^{90}$ Negotiated via the WHO, the FCTC set out a comprehensive policy approach and signalled globally that the tobacco industry, its products and smoking itself had fallen outside the boundaries of acceptability. ${ }^{91} 92$

Global regulation and continuing exposure of tobacco companies' duplicity began changing public sentiment, ${ }^{6392}$ and growing evidence of smoking's threat to human, social and economic well-being provided a clear mandate for political action. ${ }^{93-95}$ For many countries, the question was no longer what regulators would do to protect citizens from smoking, but how far they would go to end the tobacco epidemic.

\section{PHASE 5: ENDGAMES AND SOCIAL NORMS}

As denormalisation of tobacco companies and their products grew, discussions within the research and advocacy communities began to focus less on controlling the tobacco epidemic and more on ending it. ${ }^{96-99}$ Although endgame definitions vary, ${ }^{98}$ the concept implies a shift in attention from individual action to the government leadership needed to restructure tobacco marketplaces and products. ${ }^{97}$

This important change challenges depictions of smoking as a personal choice, where individuals carry responsibility for health outcomes they could have neither foreseen nor accepted, given the uncertainty created by tobacco companies. Endgames also recognise that tobacco industry initiatives to foster cessation or deter smoking uptake among youth have never privileged public health goals over profit. ${ }^{100101}$ Further, this approach understands that commercial and fiduciary imperatives will inevitably lead tobacco companies to impede and oppose any policy that 
could reduce their profitability. Endgame proponents argue that, as smoked tobacco is an inherently dangerous product, governments should treat it as such and protect their citizens by setting a date at which smoking prevalence falls to minimal levels. ${ }^{97}$ Several countries, including New Zealand, ${ }^{102}$ Finland ${ }^{103}$ and Scotland, ${ }^{104}$ have now set endgame goals that specify clear outcomes (reductions in smoking prevalence to $5 \%$ ) and timelines (2025; 2030 and 2034, respectively).

Establishing a timeline to end the smoking pandemic requires measures that will catalyse profound declines in smoking prevalence and go beyond 'demand-side' policies, such as restricting tobacco marketing. Although these latter policies have achieved much, particularly given aggressive industry opposition, ${ }^{105} 106$ they implicitly accept industry claims that smoking is a personal 'habit'; if smoking is a matter of individual choice, the need for structural changes to tobacco markets is less obvious. ${ }^{107}$

By contrast, 'supply-side' policies, involving systemic changes that restructure tobacco marketplaces, reconsider the design and availability of tobacco products, and envisage a point when these are no longer supplied using a commercial market model. ${ }^{93} 97107$ While potential approaches differ in how much they retain or remove free-market attributes, ${ }^{107-109}$ all focus on measures that will change how tobacco companies operate and the products they may manufacture. Endgame strategies also use growing public recognition that smoked tobacco is not a normal product made by a legitimate industry to propose transformational measures. ${ }^{110}$

Yet, despite low trust in tobacco companies, ${ }^{111}$ countries with an endgame goal have been slow to implement supply-side measures, ${ }^{112}{ }^{113}$ leading to grave concerns the timelines set will not be met (though New Zealand's pending Action Plan may yet see the goal realised in that country). ${ }^{114}$ Limited progress may partly reflect tobacco companies' success in shaping social norms regarding public health policy. They and other corporates have framed protective measures as 'nanny state' interference that compromises personal freedoms, funded neoliberal front groups to repeat these assertions and promoted public distaste for regulation. ${ }^{105} 115-117$

Tobacco companies have also attempted to reclaim social legitimacy for themselves and their products, a mission started following the Frank Statement's publication. Denied the ability to integrate their brands into everyday life via sponsorship and other lifestyle marketing, tobacco companies replaced mainstream marketing with targeted corporate social responsibility (CSR) initiatives. CSR presents companies as caring and responsible corporate citizens, provides lobbying opportunities and embeds commercial entities within communities. For example, industry-funded 'education' programmes responded to public concern over smoking among young people (though did nothing to decrease the risk of smoking initiation). ${ }^{101}$ Environmental initiatives fund local clean-up operations to remove tobacco product waste (though do nothing to change the origin of this problem). ${ }^{118}$ Tobacco companies have also seized opportunities in developing countries to support sustainable tobacco plantations and assist local economies by providing disaster relief or educational resources. ${ }^{19} 120$

More recently, tobacco companies have positioned themselves as pioneers developing COVID-19 vaccines, or as benefactors providing medical supplies to assist countries struggling to respond to COVID-19. ${ }^{121} 122$ Although CSR strategies predate endgame dialogue and exist in countries yet to set endgame goals, they illustrate the priority the industry places on social acceptability and its skill in positioning itself as a source of solutions rather than a creator of problems. ${ }^{119}$
CSR has created doubt that the industry is irredeemable and recent declarations of self-transformation augment this doubt. ${ }^{123-125}$ Tobacco companies have declared they will eliminate smoked tobacco products, thus implicitly recognising these products will never again be socially acceptable. Nonetheless, their failure to provide a timeline and aggressive promotion of smoked tobacco in countries with less stringent regulation questions these stated intentions. ${ }^{126} 127$ The industry's apparent volte-face evokes the Frank Statement rhetoric; they are again presenting themselves as public health allies and are now offering a 'solution': reduced-harm products, such as electronic nicotine delivery systems (ENDS) and heated tobacco products (HTPs).

Tobacco companies' chameleonic capacity for reinvention and audacious belief they may reframe themselves as a solution to the destruction caused by their combustible products presents new and troubling questions. ENDS marketing has made electronic nicotine products symbols of social capital that connect young people and enable them to bridge social boundaries. ${ }^{128-131}$ Social media platforms, social influencers and music festivals have replaced tobacco product placement in movies and endorsements by film stars. ${ }^{132-135}$ These promotions are associated with rapid ENDS uptake among never-smoking young people and have led to widespread concerns that ENDS marketing will create new generation dependent on nicotine. ${ }^{136}$

Corporate strategy documents support these concerns and show growth in non-combustible products has come more from 'new entrants' than from switchers. ${ }^{137}$ Furthermore, rather than trigger switching and then eventual ENDS or HTP cessation, tobacco companies plan to promote long-term ENDS use among current and former smokers and see their products as 'additive'. ${ }^{138}$

Renormalisation has seen industry language integrated into common discourse (eg, promotion of ENDS to 'quit' rather than 'switch', wording that conveniently overlooks the burden of continuing nicotine dependence). ${ }^{139}$ Philip Morris has framed its IQOS HTP as 'smoke-free' to capitalise on the reduced risk profile associated with ENDS, ${ }^{140}$ despite evidence HTPs may carry similar risks to smoked tobacco and are almost certainly more harmful than ENDS. ${ }^{141}$ This rhetorical chicanery reinforces claims the industry offers solutions, not problems, enables them to regain political capital and depicts them as legitimate stakeholders in tobacco control policy debates. ${ }^{142-145}$

The endgame phase has seen the tobacco industry renew its interest in research alliances. Following an undertaking given in the Frank Statement, tobacco companies funded the Tobacco Industry Research Committee, which internal industry documents revealed as a public relations front used to dispute evidence of smoking's harms. ${ }^{44} 146147$ Philip Morris's Foundation for a Smokefree World (FSFW), of which it remains the sole funder, has also funded 'research' centres. ${ }^{148}$ Yet, scrutiny of the FSFW's governing documents questions its independence from Philip Morris. ${ }^{149}$ Furthermore, FSFW 'research' centres have focused strongly on 'harm-reduction' products while opposing evidence-based policies that would constrain tobacco companies and attacking public health researchers. ${ }^{150} 151$

Doubt and division, first created half a century ago by the Frank Statement, again threatens to fracture the public health community and create rifts between those who believe the industry may reform and regain social acceptance, and those who do not. ${ }^{152}$ Philip Morris International (PMI) strategy documents reveal similar 'divide-and-conquer' plans. The company aims to amplify the voices of harm reduction proponents, achieve 'normalisation' by presenting 'anti-tobacco opponents' as having 'double standards' and build political goodwill by engaging 
'non-traditional' third parties, including those from the scientific community. ${ }^{153}$ Given these tactics, it is not surprising that views on new nicotine products range from the utilitarian, which accepts the promise of overall harm reduction, to the deontological, which rejects interactions with tobacco companies because of their historical duplicity, continued sales of smoked tobacco products and overt targeting of electronic nicotine products to youth.

Industry reinvention strategies bring their framing of smoking as an individual choice into stark relief and raise new questions about how denormalisation (and industry renormalisation) affect people who smoke. ${ }^{154}$ Depicting these people as having made poor choices they could rectify enables tobacco companies to position themselves as corporate saviours offering a novel 'solution'. Personal choice narratives, such as PMI's proposition that people 'unsmoke' their world by switching to IQOS, foster tobacco companies' personae as reformed corporate characters, but invite judgement of people who smoke. That judgement may be internalised and experienced as stigma, ${ }^{155-157}$ which may compound other disadvantages. ${ }^{158} 159$ As smoking prevalence falls, people who continue smoking may feel socially excluded or of lesser value; these feelings may entrench their smoking identities and practices, and undermine the self-efficacy needed for successful quit attempts. ${ }^{160-162}$

To avoid inadvertently reinforcing industry-inspired norms and alienating those who should benefit most from smoke-free goals, endgame strategies should build on, and enable, leadership within communities most harmed by commercial tobacco and at greatest risk of stigma. Leadership from within these communities will provide a broader perspective on tobacco (eg, commercial vs traditional/sacred use) and its effects on health and well-being. Western (medical) perspectives of health have dominated current thinking, focus on biological impacts of tobacco use and risk presenting endgame goals in terms of minimisation. Because Indigenous people's experiences of commercial tobacco occurred via colonisation, Western perspectives often overlook the impacts of tobacco use on their social, economic and physical health and well-being. Indigenous leaders, who responded to the havoc commercial tobacco products caused to their communities by proposing endgame solutions, may be well placed to reclaim smoke-free norms and guide the return to traditional smokefree practices. ${ }^{163}$ Enabling Indigenous leaders to restore traditional practices requires the endgame phase to prioritise equity, develop partnership approaches and encourage community-led initiatives.

\section{CONCLUSION}

Tobacco companies manipulated social norms to establish smoking as a socially accepted practice and encourage uptake among all population groups. As knowledge of smoking's addictiveness and harms became incontrovertible, smoking prevalence plateaued then decreased. Smoking as a practice, and tobacco companies as corporate actors, lost status and legitimacy; these changes have protected young people from smoking uptake and triggered quitting among those who smoked. However, tobacco companies have opposed regulation that reinforces their loss of social acceptability and fought hard to regain political influence, community trust and goodwill.

Denormalisation has stimulated new thinking about tobacco endgames that would bring fundamental changes to tobacco markets and products, and shift responses from people who smoke to tobacco companies. However, tobacco companies' quest for renormalisation, elaborate CSR initiatives, self-proclaimed transformations, product 'innovations' and efforts to undermine a once united public health sector raise new and serious questions. Tobacco endgames can be realised, though history suggests governments, not industry renormalisation, will achieve these goals. It is thus crucial that regulators resist industry blandishments, recognise that only they can unsmoke the world and introduce powerful measures to ensure the endgame phase is indeed the final phase of the smoking epidemic.

Acknowledgements The authors thank Emeritus Professor Phil Gendall for pithy comments on the penultimate version of the manuscript.

Contributors $\mathrm{JH}$ conceptualised and planned the manuscript; RE and AW commented on the manuscript plan. JH wrote and developed the manuscript; RE and AW commented on an advanced draft. JH undertook the revisions. All authors have approved the final manuscript.

Funding All authors are funded by the University of Otago, New Zealand.

Competing interests None declared.

Patient consent for publication Not required.

Provenance and peer review Commissioned; externally peer reviewed.

\section{ORCID iDs}

Janet Hoek http://orcid.org/0000-0003-4362-1539

Richard Edwards http://orcid.org/0000-0003-2264-9823

Andrew Waa http://orcid.org/0000-0002-8078-0283

\section{REFERENCES}

1 Young HP. The evolution of social norms. Annu Rev Econom 2015;7:359-87.

2 Legros S, Cislaghi B. Mapping the social-norms literature: an overview of reviews. Perspect Psychol Sci 2020;15:62-80.

3 Kobus K. Peers and adolescent smoking. Addiction 2003;98 Suppl 1:37-55.

4 Blue S, Shove E, Carmona C, et al. Theories of practice and public health: understanding (un)healthy practices. Crit Public Health 2016;26:36-50

5 Johnson JL, Lovato CY, Maggi S, et al. Smoking and adolescence: narratives of identity. Res Nurs Health 2003;26:387-97.

6 Brillinger J, Marsh L, Hoek J. Bar Atmospherics and smoking: a qualitative analysis of new Zealand young adult smokers. Nicotine Tobacco Research 2021:23:724-31.

7 Robinson DJ. Cigarette marketing and smoking culture in 1930s Canada. Journal of the Canadian Historical Association 2014;25:63-105.

8 Lee JP, Moore RS, Martin SE. Unobtrusive observations of smoking in urban California bars.J Drug Issues 2003:33:983-99.

9 Platter HN, Pokorny SB. Smoke-Free signage in public parks: impacts on smoking behaviour. Tob Control 2018:27:470-3.

10 Kelly BC, Vuolo M, Frizzell LC, et al. Denormalization, smoke-free air policy, and tobacco use among young adults. Soc Sci Med 2018:211:70-7.

11 Dunlop S, Kite J, Grunseit AC, et al. Out of sight and out of mind? evaluating the impact of Point-of-Sale tobacco display bans on smoking-related beliefs and behaviors in a sample of Australian adolescents and young adults. Nicotine Tob Res 2015;17:761-8

12 Shadel WG, Martino SC, Setodji CM, et al. Hiding the tobacco power wall reduces cigarette smoking risk in adolescents: using an experimental convenience store to assess tobacco regulatory options at retail point-of-sale. Tob Control 2016;25:679-84

13 Lopez AD, Collishaw NE, Piha T. A descriptive model of the cigarette epidemic in developed countries. Tob Control 1994;3:242-7.

14 Thun M, Peto R, Boreham J, et al. Stages of the cigarette epidemic on entering its second century. Tob Control 2012;21:96-101.

15 Rogers EM, Singhal A, Quinlan MM. Diffusion of innovations. Routledge, 2014.

16 Nord WR, Peter JP. A behavior modification perspective on marketing. J Mark 1980;44:36-47

17 Pampel FC. Diffusion, cohort change, and social patterns of smoking. Soc Sci Res 2005;34:117-39.

18 Mahaney FX. Oldtime ads tout health benefits of smoking: tobacco industry had doctors' help. J Natl Cancer Inst 1994;86:1048-9.

19 Gardner MN, Brandt AM. "The doctors' choice is America's choice": the physician in US cigarette advertisements, 1930-1953. Am J Public Health 2006;96:222-32.

20 Gardiner PS. The African Americanization of menthol cigarette use in the United States. Nicotine Tob Res 2004;6 Suppl 1:55-65.

21 Cruz TB, Wright LT, Crawford G. The menthol marketing mix: targeted promotions for focus communities in the United States. Nicotine Tob Res 2010;12 Suppl 2:S147-53.

22 Iglesias-Rios L, Parascandola M. A historical review of R.J. Reynolds' strategies for marketing tobacco to Hispanics in the United States. Am J Public Health 2013;103:e15-27 
$23 \operatorname{Amos}$ A, Haglund M. From social taboo to "torch of freedom": the marketing of cigarettes to women. Tob Control 2000;9:3-8.

24 Washington HA. Burning love: big tobacco takes aim at LGBT youths. Am J Public Health 2002;92:1086-95.

25 Richardson A, Ganz O, Pearson J, et al. How the industry is marketing menthol cigarettes: the audience, the message and the medium. Tob Control 2015;24:594-600.

26 Anderson SJ, Glantz SA, Ling PM. Emotions for sale: cigarette advertising and women's psychosocial needs. Tob Control 2005;14:127-35.

27 Remafedi G. Lesbian, gay, bisexual, and transgender youths: who smokes, and why? Nicotine Tob Res 2007;9 Suppl 1:S65-71.

28 Kidd E, Kemp N, Quinn S. Did you have a choccie bickie this arvo? A quantitative look at Australian hypocoristics. Language Sciences 2011;33:359-68.

29 Toll BA, Ling PM. The Virginia Slims identity crisis: an inside look at tobacco industry marketing to women. Tob Control 2005;14:172-80.

30 Smith EA, Thomson K, Offen N, et al. "If you know you exist, it's just marketing poison": meanings of tobacco industry targeting in the lesbian, gay, bisexual, and transgender community. Am J Public Health 2008;98:996.

31 Alves T. A Quick Guide to 'Smoko', the Australasian Smoke Break, 2017. Available: https://theculturetrip.com/pacific/new-zealand/articles/a-quick-guide-to-smoko-theaustralasian-smoke-break/

32 Chapman S, Davis RM. Smoking in movies: is it a problem? Tob Control 1997;6:269

33 Mekemson C, Glantz SA. How the tobacco industry built its relationship with Hollywood. Tob Control 2002;11 Suppl 1:i81-91.

34 Dalton MA, Sargent JD, Beach ML, et al. Effect of viewing smoking in movies on adolescent smoking initiation: a cohort study. Lancet 2003;362:281-5.

35 Song AV, Ling PM, Neilands TB, et al. Smoking in movies and increased smoking among young adults. Am J Prev Med 2007;33:396-403

36 Campaign for tobacco-free kids. U.S. District Judge Gladys Kessler's Final Opinion: Summary of Findings Against the Tobacco Industry. Available: http://www.tobaccofreekids.org/content/what_we_do/industry_watch/doj/ FinalOpinionSummary.pdf

37 Pollay RW. How cigarette advertising works: rich imagery and poor information, 2000b.

38 Proctor RN. Tobacco and the global lung cancer epidemic. Nat Rev Cancer 2001;1:82-6.

39 Doll R, Hill AB. Lung cancer and other causes of death in relation to smoking. BMJ 1956;2:1071-81.

40 Wynder EL, Graham EA. Tobacco smoking as a possible etiologic factor in bronchiogenic carcinoma; a study of 684 proved cases. J Am Med Assoc 1950;143:329-36

41 Cummings KM, Morley CP, Hyland A. Failed promises of the cigarette industry and its effect on consumer misperceptions about the health risks of smoking. Tob Control 2002;11 Suppl 1:i110-7.

42 Oreskes N, Conway EM. Merchants of doubt: how a handful of scientists obscured the truth on issues from tobacco smoke to global warming. Bloomsbury Publishing USA, 2011

43 Michaels D, Monforton C. Manufacturing uncertainty: contested science and the protection of the public's health and environment. Am J Public Health 2005;95 Suppl 1:S39-48.

44 Brandt AM. Inventing conflicts of interest: a history of tobacco industry tactics. Am J Public Health 2012:102:63-71.

45 Samet JM, Burke TA. Turning science into junk: the tobacco industry and passive smoking. Am J Public Health 2001;91:1742-4.

46 Landman A, Glantz SA. Tobacco industry efforts to undermine policy-relevant research. Am J Public Health 2009;99:45-58.

47 Ong EK, Glantz SA. Constructing "sound science" and "good epidemiology": tobacco, lawyers, and public relations firms. Am J Public Health 2001;91:1749-57.

48 Lorillard Tobacco Company. Kent advertisement, 1954. Available: http://tobacco. stanford.edu/tobacco_main/images.php?token2 $=\mathrm{fm} \_$st079.php\&token $1=\mathrm{fm}$ img42631.php\&theme_file $=f m \_m t 006$.php\&theme_name $=$ Filter $\% 20$ Safety $\%$ 20Myths\&subtheme_name=Protects $\% 20$ Your $\% 20$ Health

49 Harris B. The intractable cigarette 'filter problem'. Tob Control 2011;20 Suppl 1:i10-16.

50 Novotny TE, Lum K, Smith E, et al. Cigarettes butts and the case for an environmental policy on hazardous cigarette waste. Int J Environ Res Public Health 2009:6:1691-705.

51 Song M-A, Benowitz NL, Berman M, et al. Cigarette filter ventilation and its relationship to increasing rates of lung adenocarcinoma. J Natl Cancer Inst 2017;109:djx075.

52 Borland R, Yong H-H, King B, et al. Use of and beliefs about light cigarettes in four countries: findings from the International tobacco control policy evaluation survey. Nicotine Tob Res 2004;6 Suppl 3:S311-21.

53 King B, Borland R. What was "light" and "mild" is now "smooth" and "fine": new labelling of Australian cigarettes. Tob Control 2005;14:214-5.

54 Borland R, Fong GT, Yong H-H, et al. What happened to smokers' beliefs about light cigarettes when "light/mild" brand descriptors were banned in the UK? Findings from the International Tobacco Control (ITC) Four Country Survey. Tob Control 2008:17:256-62

55 Henriksen L. Comprehensive tobacco marketing restrictions: promotion, packaging, price and place. Tob Control 2012;21:147-53.

56 Carter SM, Chapman S. Smoking, disease, and obdurate denial: the Australian tobacco industry in the 1980s. Tob Control 2003:12 Suppl 3:iii23-30.

57 Warner KE. Effects of the antismoking campaign: an update. Am J Public Health 1989;79:144-51

58 Gallopel-Morvan K, Gabriel P, Le Gall-Ely M, et al. The use of visual warnings in social marketing: the case of tobacco. J Bus Res 2011;64:7-11.

59 Hammond D, Fong GT, McDonald PW, et al. Graphic Canadian cigarette warning labels and adverse outcomes: evidence from Canadian smokers. Am J Public Health 2004;94:1442-5.

60 Wakefield M, Freeman J, Donovan R. Recall and response of smokers and recent quitters to the Australian National tobacco campaign. Tob Control 2003;12 Suppl 2:ii15-22.

61 DiFranza JRet al. Legislative efforts to protect children from tobacco. JAMA 1987;257:3387-9.

62 Chaloupka FJ, Grossman M. Price, tobacco control policies and youth smoking. National Bureau of Economic Research, 1996.

63 Cummings KM, Brown A, O'Connor R. The cigarette controversy. Cancer Epidemiol Biomarkers Prev 2007:16:1070-6.

64 Bates C, Rowell A. Tobacco explained. The truth about the tobacco industry. in its own words. eScholarship Repository: University of California, 2004. https:// escholarship.org/content/qt9fp6566b/qt9fp6566b.pdf

65 Henningfield JE, Rose CA, Zeller M. Tobacco industry litigation position on addiction: continued dependence on past views. Tob Control 2006;15 Suppl 4:iv27-iv-36.

66 Ling PM, Glantz SA. Why and how the tobacco industry sells cigarettes to young adults: evidence from industry documents. Am J Public Health 2002;92:908-16.

67 Schroeder SA. Tobacco control in the wake of the 1998 master settlement agreement. N Engl J Med 2004;350:293-301.

68 Healton C. Who's afraid of the truth? Am J Public Health 2001:91:554-8.

69 Farrelly MC, Nonnemaker J, Davis KC, et al. The influence of the National truth campaign on smoking initiation. Am J Prev Med 2009;36:379-84.

70 Vallone D, Cantrell J, Bennett $M$, et al. Evidence of the impact of the truth Finishlt campaign. Nicotine Tob Res 2018;20:543-51

71 McCarthy EJ, Shapiro SJ, Perreault WD. Basic marketing. Irwin-Dorsey Ontario, 1979

72 Chapman S, Freeman B. Markers of the denormalisation of smoking and the tobacco industry. Tob Control 2008;17:25-31.

73 World Health Organization. Tobacco, 2021. Available: https://www.who.int/newsroom/fact-sheets/detail/tobacco

74 Daynard RA, de Alwis RdeS, Gottlieb M. Allying tobacco control with human rights: invited commentary. Tob Control 2012;21:213-4.

75 Hyland A, Barnoya J, Corral JE. Smoke-Free air policies: past, present and future. Tob Control 2012;21:154-61.

76 Mark AJ, Sanders SC, Mitchell JA, et al. Smoke-Free outdoor areas: supporting local government to introduce tobacco control policies. Aust N Z J Public Health 2014;38:518-23.

77 Tong EK, Glantz SA. Tobacco industry efforts undermining evidence linking secondhand smoke with cardiovascular disease. Circulation 2007:116:1845-54

78 Ong EK, Glantz SA. Tobacco industry efforts subverting International Agency for Research on Cancer's second-hand smoke study. The Lancet 2000:355:1253-9.

79 Hong M-K, Bero LA. How the tobacco industry responded to an influential study of the health effects of secondhand smoke. BMJ 2002;325:1413-6.

80 Hirschhorn N, Bialous SA. Second hand smoke and risk assessment: what was in it for the tobacco industry? Tob Control 2001;10:375-82.

81 Smith EA, Malone RE. 'We will speak as the smoker': the tobacco industry's smokers' rights groups. Eur J Public Health 2007;17:306-13.

82 Cardador MT, Hazan AR, Glantz SA. Tobacco industry smokers' rights publications: a content analysis. Am J Public Health 1995;85:1212-7.

83 Poland BD. The 'considerate' smoker in public space: the micro-politics and political economy of 'doing the right thing'. Health Place 2000;6:1-14.

84 Thomson G, Wilson N. The tobacco industry in New Zealand: a case study of the behaviour of multinational companies, 2003. Available: https://escholarship.org/uc/ item/0bd8z7s2

85 Sharfstein J. Blowing smoke: how cigarette manufacturers argued that nicotine is not addictive. Tob Control 1999;8:210-3

86 Gray RJ, Hoek J, Edwards R. A qualitative analysis of 'informed choice' among young adult smokers. Tob Control 2016;25:46-51.

$87 \mathrm{McCool}$ J, Freeman B, Thomson G. Public and media responses to the first tobacco litigation trial in New Zealand (POU versus bat). Social Policy Journal of New Zealand 2009:34:152-62

88 Tokeley K. Case Note: Pou v British American Tobacco (NZ) Ltd - a Comprehensive Win for the New Zealand Tobacco Industry. Waikato Law Review: Taumauri 2006:14:136-44.

89 Wakefield M, McLeod K, Smith KC. Individual versus corporate responsibility for smoking-related illness: Australian press coverage of the Rolah McCabe trial. Health Promot Int 2003;18:297-305 
90 World Health Organization. Framework convention on tobacco control, 2003. Available: http://www.who.int/tobacco/en/

91 McDaniel PA, Malone RE. The role of corporate credibility in legitimizing disease promotion. Am J Public Health 2009;99:452-61.

92 Hammond D, Fong GT, Zanna MP, et al. Tobacco denormalization and industry beliefs among smokers from four countries. Am J Prev Med 2006:31:225-32.

93 Malone RE, Grundy Q, Bero LA. Tobacco industry denormalisation as a tobacco control intervention: a review. Tob Control 2012:21:162-70.

94 Burns D. How far we have come in the last 50 years in smoking attitudes and actions. Ann Am Thorac Soc 2014:11:224-6.

95 Marwick C. Effects of 'passive smoking' lead nonsmokers to step up campaign. JAMA 1985:253:2937-9.

96 Malone RE. Imagining things otherwise: new endgame ideas for tobacco control. Tob Control 2010:19:349-50.

97 Malone RE. Tobacco endgames: what they are and are not, issues for tobacco control strategic planning and a possible us scenario. Tob Control 2013;22 Suppl $1: i 42-4$

98 McDaniel PA, Smith EA, Malone RE. The tobacco endgame: a qualitative review and synthesis. Tob Control 2016;25:594-604.

99 Smith EA, Malone RE. An argument for phasing out sales of cigarettes. Tob Control 2020:29:703-8.

100 McDaniel PA, Lown EA, Malone RE. "It doesn't seem to make sense for a company that sells cigarettes to help smokers stop using them": A case study of Philip Morris's involvement in smoking cessation. PLoS One 2017;12:e0183961.

101 Wakefield M, McLeod K, Perry CL. "Stay away from them until you're old enough to make a decision": tobacco company testimony about youth smoking initiation. Tob Control 2006;15 Suppl 4:iv44-53.

102 New Zealand Government. Government response to the report of the Maori Affairs select Committee on its inquiry into the tobacco industry in Aotearoa and the consequences of tobacco use for Maori. Wellington, NZ: New Zealand Government, 2011. https://www.parliament.nz/resource/en-nz/49DBHOH_PAP21175_1/9f01 5010d386fe11050cddfbb468c2a3f5b0cb899f015010d386fe11050cddfbb468c2a3 f5b0cb899f015010d386fe11050cddfbb468c2a3f5b0cb899f015010d386fe11050c ddfbb468c2a3f5b0cb89

103 Timberlake DS, Laitinen U, Kinnunen JM, et al. Strategies and barriers to achieving the goal of Finland's tobacco endgame. Tob Control 2020;29:398-404.

104 The Scottish Government. Creating a tobacco-free generation: a tobacco control strategy for Scotland. Edinburgh: The Scottish Government, 2013. https://www. webarchive.org.uk/wayback/archive/3000/https://www.gov.scot/resource/0041/ 00417331.pdf

105 Waa AM, Hoek J, Edwards R, et al. Analysis of the logic and framing of a tobacco industry campaign opposing standardised packaging legislation in New Zealand. Tob Control 2017;26:629-33.

106 Freeman B. Tobacco plain packaging legislation: a content analysis of commentary posted on Australian online news. Tob Control 2011;20:361-6.

107 Callard CD, Collishaw NE. Supply-Side options for an endgame for the tobacco industry. Tob Control 2013;22 Suppl 1:i10-13.

108 Callard C, Thompson D, Collishaw N. Transforming the tobacco market: why the supply of cigarettes should be transferred from for-profit corporations to non-profit enterprises with a public health mandate. Tob Control 2005;14:278-83.

109 Borland R. A strategy for controlling the marketing of tobacco products: a regulated market model. Tob Control 2003;12:374-82.

110 Ministry of Health. Proposals for a Smokefree Aotearoa 2025 action plan. Wellington: Ministry of Health, 2021. https://www.health.govt.nz/publication/ proposals-smokefree-aotearoa-2025-action-plan

111 Moodie C, Sinclair L, Mackintosh AM, et al. How tobacco companies are perceived within the United Kingdom: an online panel. Nicotine Tob Res 2016;18:1766-72.

112 Wilson N, Blakely T, Hoek J, et al. The government's goal for a Smokefree New Zealand by 2025: more decisions, and more detail, are urgently needed. N Z Med J 2011;124:111-3.

113 Thornley L, Edwards R, Schwartz R. What is happening in countries with tobacco endgame goals? findings from the inspired (network to share insights on tobacco Endgames) project. 23rd IUHPE World Conference on Health Promotion. Rotorua, New Zealand, 2019

114 Wilson N, Petrović-van der Deen FS, Edwards R, et al. Modelling the number of quitters needed to achieve New Zealand's Smokefree 2025 goal for Māori and nonMāori. N Z Med J 2018;131:30-7.

115 Hoek J. Informed choice and the nanny state: learning from the tobacco industry. Public Health 2015;129:1038-45.

116 Gornall J. Big tobacco, the new politics, and the threat to public health. BMJ $2019 \cdot 365: 12164$

117 Moodie R, Stuckler D, Monteiro C, et al. Profits and pandemics: prevention of harmful effects of tobacco, alcohol, and ultra-processed food and drink industries. Lancet 2013;381:670-9

118 Smith EA, McDaniel PA. Covering their butts: responses to the cigarette litter problem. Tob Control 2011;20:100-6.
119 McDaniel PA, Cadman B, Malone RE. Shared vision, shared vulnerability: a content analysis of corporate social responsibility information on tobacco industry websites. Prev Med 2016;89:337-44.

120 Fang J, Yang G, Wan X. 'Pro-tobacco propaganda': a case study of tobacco industrysponsored elementary schools in China. Tob Control 2020;29:447-51.

121 British Amercian Tobacco. Bat progresses COVID-19 candidate vaccine into phase I human clinical trials, 2020. Available: https://www.bat.com/group/sites/UK__ 9D9KCY.nsf/vwPagesWebLive/DOBWBPMP\#

122 Girvalaki C, Mechili E, Loghin C, et al. Social responsibility during the COVID-19 pandemic: Tobacco industry's trojan horse in Europe. Tob Prev Cessat 2020;6.

123 Fooks G, Gilmore A, Collin J, et al. The limits of corporate social responsibility: techniques of neutralization, Stakeholder management and political Csr. J Bus Ethics 2013:112:283-99.

124 Bowles J, Marroco T. Enterprise of the future: transformation and growth. British American Tobacco, 2021. https://www.bat.com/group/sites/uk_9d9kcy.nsf/ vwPagesWebLive/D06FKEVZ/\$FILE/medMDBYCMVH.pdf?openelement

125 Philip Morris International. Our transformation: delivering a smoke-free future, 2019. Available: https://www.pmi.com/our-transformation/delivering-a-smoke-freefuture

126 Gilmore AB, Fooks G, Drope J, et al. Exposing and addressing tobacco industry conduct in low-income and middle-income countries. Lancet 2015:385:1029-43.

127 Koh HK, Geller AC. The Philip Morris International-Funded foundation for a smokefree world. JAMA 2018;320:131-2.

128 Dai H, Hao J. Exposure to advertisements and susceptibility to electronic cigarette use among youth. J Adolesc Health 2016;59:620-6.

129 Hammond D, Reid JL, Burkhalter R, et al. E-Cigarette marketing regulations and youth Vaping: cross-sectional surveys, 2017-2019. Pediatrics 2020;146:e20194020.

130 Amin S, Dunn AG, Laranjo L. Social influence in the uptake and use of electronic cigarettes: a systematic review. Am J Prev Med 2020;58:129-41.

131 Kong G, LaVallee H, Rams A, et al. Promotion of vape tricks on YouTube: content analysis. J Med Internet Res 2019;21:e12709.

132 Phua J, Jin SV, Hahm JM. Celebrity-endorsed e-cigarette brand Instagram advertisements: effects on young adults' attitudes towards e-cigarettes and smoking intentions. J Health Psychol 2018;23:550-60.

133 Hoek J, Freeman B. BAT(NZ) draws on cigarette marketing tactics to launch Vype in New Zealand. Tob Control 2019;28:e162-3.

134 Cochran C, Robertson L, Hoek J. Online marketing activity following New Zealand's vaping legislation. Tob Control 2021. doi:10.1136/tobaccocontrol-2021-056750. [Epub ahead of print: 22 Jul 2021].

135 Padon AA, Maloney EK, Cappella JN. Youth-Targeted e-cigarette marketing in the US Tob Regul Sci 2017;3:95-101.

136 Measham F, O'Brien K, Turnbull G. "Skittles \& Red Bull is my favourite flavour": E-cigarettes, smoking, vaping and the changing landscape of nicotine consumption amongst British teenagers - implications for the normalisation debate. Drugs: Education, Prevention and Policy 2016;23:224-37

137 Tobacco Tactics. E-Cigarettes: British American tobacco. United Kingdom: University of Bath, 2021. https://tobaccotactics.org/wiki/e-cigarettes-british-american-tobacco/

138 British Amercian Tobacco. Innovative choices, responsible growth: 2018 harm reduction focus report, 2018. Available: https://www.bat.com/group/sites/UK 9D9KCY.nsf/vwPagesWebLive/D0964UGU/\$file/Harm_Reduction_Focus_Report_ 2018.pdf

139 O'Connor R, Durkin SJ, Cohen JE, et al. Thoughts on neologisms and pleonasm in scientific discourse and tobacco control. Tob Control 2021:30:359-60.

140 Evans-Reeves K, Gilmore A. Addiction at any cost. PMI uncovered. Bath, United Kingdom: University of Bath, 2020. https://exposetobacco.org/wp-content/uploads/ STOP_Report_Addiction-At-Any-Cost.pdf

141 Auer R, Concha-Lozano N, Jacot-Sadowski I, et al. Heat-Not-Burn tobacco cigarettes: smoke by any other name. JAMA Intern Med 2017;177:1050-2.

142 Robertson L, Hoek J, Gilmore A. Regulating vaping and new nicotine products: Are tobacco companies' goals aligned with public health objectives. Otago: Public Health Expert New Zealand, 2020. https://blogs.otago.ac.nz/pubhealthexpert/ regulating-vaping-and-new-nicotine-products-are-tobacco-companies-goals-alignedwith-public-health-objectives/

143 Thompson S, Smith J, Lee K, et al. Industry sponsored harm reduction conference courts Indigenous peoples in Canada. Tob Control 2020;29:e130-1.

144 Waa A, Maddox R, Nez Henderson P. Big tobacco using Trojan horse tactics to exploit Indigenous peoples. Tob Control 2020;29:e132-3.

145 Malone RE, Hoek J. Political ineptitude, public anxiety and the undermining of the WHO. Tob Control 2020;29:361-2.

146 Bero LA. Tobacco industry manipulation of research. Public Health Rep 2005;120:200-8

147 Warner KE. Tobacco industry scientific advisors: serving Society or selling cigarettes? Am J Public Health 1991:81:839-42.

148 Tobacco Tactics. 'Foundation for a smokefree world'. UK: University of Bath, 2021. https://tobaccotactics.org/wiki/foundation-for-a-smoke-free-world/

149 van der Eijk Y, Bero LA, Malone RE. Philip Morris International-funded 'Foundation for a Smoke-Free World': analysing its claims of independence. Tob Control 2019;28:712-8. 
150 Glover M. Do we really need another law? the cost to new Zealand of banning smoking in cars: health select Committee submission. Auckland: COREISS, 2019. https://coreiss.com/file/display/publication/4/do_we_really_need_another_law. pdf

151 Caruana D. Dr. Siegel about PMI's 'Foundation for a Smoke-Free World', 2017. Available: https://www.vapingpost.com/2017/12/07/dr-siegel-about-pmisfoundation-for-a-smoke-free-world/

152 McDaniel PA, Smith EA, Malone RE. Philip Morris's project Sunrise: weakening tobacco control by working with it. Tob Control 2006;15:215-23.

153 Philip Morris International. 10 year corporate Affairs objectives and strategies. Philip Morris International, 2014. https://www.documentcloud.org/documents/433339510-Year-Corporate-Affairs-Objectives-and

154 Friedman LC, Cheyne A, Givelber D, et al. Tobacco industry use of personal responsibility rhetoric in public relations and litigation: disguising freedom to blame as freedom of choice. Am J Public Health 2015;105:250-60.

155 Bayer R, Fairchild AL. Stigma: time for a hard conversation. Int J Drug Policy 2015;26:613-4.

156 Bayer R, Stuber J. Tobacco control, stigma, and public health: rethinking the relations. Am J Public Health 2006;96:47-50.
157 McCool J, Hoek J, Edwards R, et al. Crossing the smoking divide for young adults: expressions of stigma and identity among smokers and nonsmokers. Nicotine Tob Res 2013;15:552-6.

158 Graham H. Smoking, stigma and social class. J Soc Policy 2012;41:83-99.

159 Antin TMJ, Annechino R, Hunt G, et al. The gendered experience of smoking stigma: implications for tobacco control. Crit Public Health 2017;27:443-54.

160 Bell K, McCullough L, Salmon A, et al. 'Every space is claimed': smokers' experiences of tobacco denormalisation. Sociol Health IIIn 2010;32:914-29.

161 Evans-Polce RJ, Castaldelli-Maia JM, Schomerus G, et al. The downside of tobacco control? smoking and self-stigma: a systematic review. Soc Sci Med 2015;145:26-34.

162 Barbalich I, Gartner C, Edwards R, et al. New Zealand smokers' perceptions of tobacco endgame measures: a qualitative analysis. Nicotine Tob Res 2021. doi:10.1093/ntr/ntab161. [Epub ahead of print: 09 Sep 2021].

163 Māori Affairs Select Committee. Inquiry into the tobacco industry in Aotearoa and the consequences of tobacco use for Māori. Wellington: New Zealand Parliament, 2010. http://www.parliament.nz/NR/rdonlyres/C6AAA494-A706-48C6-8F916CAF5EA7CA51/164754/DBSCH_SCR_4900_InquiryintothetobaccoindustryinAotel nquiryintothetobaccoindustryinAotelnquiryintothetobaccoindustryinAotelnquiryinto thetobaccoindustryinAote.pdf 